\title{
THE PROBLEM OF THE INFORMATION SOCIETY IN MODERN PHILOSOPHICAL DISCOURSE
}

\section{Okorokova V. V.}

\section{INTRODUCTION}

Modern society is characterized by an acceleration in the pace of technological development, the creation of new intelligent technologies, and the transformation of information into the most important global resource of mankind. In other words, today's society is in a stage of development when information has become one of the core values in people's lives. The rapid development of computer technology and information technology has given impetus to the development of a society built on the use of diverse information in all spheres of life and professional activity of people: in culture, science, education, economy, health care, domestic sphere. In such a society, the main object of management is not the material objects, but the symbols, ideas, images, intelligence, knowledge ${ }^{1}$.

The intensive improvement of information technologies, which continues to be done in our time, has opened the Internet as a new, practically unexplored environment, thereby opening up a wide problem field for researchers to research. The Internet is a specific reality that did not exist before, a truly new world that opens up both its positive and negative sides to a person, thereby offering various options and possible trajectories of personal development to its users.

The Internet as a world, which, as a virtual environment, represents the real sphere of a person's realization of himself, his capabilities and abilities, his potential and, in general, his subjectivity, opens up new wide opportunities for self-development and self-realization of modern man. According to N.S. Kramarenko complex of specific features of the Internet allows us to consider it not only as a new information technology, but also as a new sociocultural environment and the sphere of human self-realization ${ }^{2}$.

We are talking about the fact that today we can unequivocally state the fact that computer communication acts not only as a new communication

1 Окорокова В.В. Образ нової соціальної реальності Постмодерну та форми його моделювання: Монографія. Одеса: ВМВ, 2018. С. 43.

2 Крамаренко Н.С., Сомов Д.С. Виртуальный мир как новое пространство самоосуществления человека. URL: https://cyberleninka.ru > article > virtualnyy-mir-kaknovoe-prostranstvo-s... 
technology characteristic of the post-nonclassical period of development of scientific knowledge, but also as a basis in the formation of future culture. Indeed, modern society is at a developmental stage when information has become one of the core values in people's lives. The rapid development of computer technology and information technology spurred the development of a society built on the use of various information in all spheres of life and professional activity of people: in culture, science, education, economics, healthcare, and the domestic sphere. In such a society, the main object of management is not material objects, but symbols, ideas, images, intelligence, knowledge.

As noted by E.I. Sukhov, in the information society investments are made at a different level than in the industrial society, that is, in the production of means of production ${ }^{3}$. The organization of labor affects only the relations of workers among themselves, and therefore the level at which production operates. Post-industrial society operates more globally at the managerial level, that is, in the mechanism of production as a whole. This action takes two main forms. Firstly, these are innovations, that is, the ability to produce new products, in particular, as a result of investments in science and technology; secondly, the management itself, that is, the ability to use complex information and communication systems.

Therefore, at present, the development of the information society is a logical stage in the development of civilization, resulting from the impact of modern information and telecommunication technologies on culture, social structure, economy, law, and the state.

\section{The information society: philosophical understanding of the concept, characteristic features}

For the first time in a fairly clear form, the idea of the information society was formulated in the late $60 \mathrm{~s}$ - early $70 \mathrm{~s}$ of the XX century. As most researchers note, the invention of the term "information society" is attributed to Yu. Hayashi, a professor at Tokyo Institute of Technology. The information society was defined as one where the computerization process will give people access to reliable sources of information, save them from routine work, and provide a high level of production automation. At the same time, production itself will also change - its product will become more "information-intensive", which means an increase in the share of innovation, design and marketing in its value; the production of an information product,

${ }^{3}$ Сухов Е.И. Информационное общество как новое общество. Теория и практика общественного развития. 2011. URL: https://cyberleninka.ru/article/n/informatsionnoeobschestvo-kak-novoe-obschestvo 
rather than a material product, will be the driving force behind the education and development of society.

Paying much attention to the transformation of human values in the information society, I. Masouda ${ }^{4}$, the head of the Institute of the Information Society and one of the authors of the Information Society Plan presented by the Computer Use Development Institute (JACUDI) put forward a concept according to which the information society will be classless and conflict-free, it will be a society of consent, with a small government and state apparatus ${ }^{5}$.

Research in this area has generated a huge variety of names and definitions of the new society. U. Daisard drew attention to this circumstance in the mid80 s, writing that the desire to express the essence of the new information age resulted in a kaleidoscope of definitions, among which the thinker noted the scientific approaches of J. Lichthheim, R. Darendorf, A. Etzioni, K. Boulding, G. Kahn, S. Alstrom, R. Seidenberg, R. Barnet ${ }^{6}$. Each of these theoreticians attached great importance to the prospects explored in this book - the evolution of an increasingly complex information and communication environment. As a result, to our time the following conceptual definitions of modern society have accumulated: "Information society" (E. Toffler, D. Bell), "post-market" (T. Burns), "post-traditional" (E. Giddens), "post-historical" (Boulding K.), "technotronic" (Z. Brzezinski), "Multidimensional" (K. Kerr), "planetary" (J. McHall), "integral type society" (P. Sorokin), "post-historical society" (J. Fukuyama), "post-industrial" (G. Odum). "Enlightened society" (C. Flexner), "risk society" (W. Beck), "open society" (J. Soros), "the knowledge-based society" (Lane R.E.), "conventional "(Pakulski J.), "active" (Etzioni A.), "good" (Bellah R.). Ultimately, obeying the "channel of American sociology", they are adapted to the cliche of the "information society", but at the same time they remain divided into qualitatively different versions of the major or minor series, promising either the apolastic horrors of the end of the world, or the idylls of a millennial paradise on Earth ${ }^{7}$.

The first researchers of the information society focused on the search and generalization of its attributes. Among the ideological theorists of the information society, first of all, one should single out such thinkers as

${ }^{4}$ Masuda $Y$. The Informational Society as Post-Industrial Society. World Future Society. Washington: World Future Society, 1981. 171 p.

5 Алексеева И.Ю. Возникновение идеологии информационного общества. URL: http://www.iis.ru/events/19981130/alexeeva.ru.html

${ }^{6}$ Дайзард У. Наступление информационного века. Новая технократическая волна на Западе. М.: Прогресс, 1986. С. 344.

7 Иванов В.Г., Лезгина М.Л. "Информационное общество" как продукт научнотехнического прогресса. Теоретический журнал “Credo”. 2005. URL: http://credonew.ru/ content/view/471/57 
D.K. Galbraith, G. Kahn, Z. Brzezinski, D. Bell, J. Beninger, K. Boulding, J. Naysbit, M. Castells, M. McLuhan, T. Stonyer, A. Toffler, A. Turen, J. Furastier. Today, it is generally accepted that of the entire galaxy of noted thinkers, the theoretical basis of this concept is the work of the American sociologist D. Bell. The scientist talks about the unfolding revolution in the organization and processing of information and knowledge, in which the computer plays a central role. The computer, according to the American sociologist, is a symbol and at the same time a material carrier of the technological revolution - it is the computer that fundamentally transforms society in the second half of the 20th century.

Thus, the key role in the new society is given to information and electronic means, providing the technical basis for its use and dissemination. In this regard, the term "information society" has become widespread, in general, duplicating the concept of "post-industrial society", and used to denote a civilization, the basis for the development and existence of which is a special substance called "information", which has the property of interaction both with the spiritual and the material world of a person and, thereby, determining both the socio-cultural life of a person and his material being ${ }^{8}$.

Another American publicist and sociologist E. Toffler, in a series of works "Shock of the Future" (1970), "Report on Ecospasm" (1975), and "The Third Wave" (1980), based on the analysis of the emergence of new communication, developed the concept of "post-industrial society" or, according to ideas of a "superindustrial society", "a superindustrial civilization"). Like D. Bell, E. Toffler identifies three main stages in the development of society - three waves in the history of civilization ${ }^{9}$. In agrarian societies, the dissemination of information was carried out through a crowd of people, as well as through the Catholic Church through organized gatherings of people. The media of the next, "second wave", are based on mass production technologies - these are newspapers, magazines, films, radio and television. He calls the post-industrial stage of development of society "the third wave." In the conditions of the third wave, information and the means of its processing and dissemination acquire the greatest importance. With the revolution in the transmission of information in society, the following changes occur. The widespread introduction of computer and new technologies allows us to create new industries and make production decentralized.

\footnotetext{
${ }^{8}$ Белл Д. Социальные рамки информационного общества. Новая технократическая волна на Западе. М.: Прогресс, 1986. С. 330.

9 Тоффлер Э. Третья волна. М.: АСТ, 2010. URL: www.read.virmk.ru>present_past_ pdf`Toffler_Tretiya_volna
} 
Distinctive features of culture in the information society are: a high level of innovation, demassification and standardization of all aspects of political and economic life, a change in the nature of work and interpersonal relationships changes the value system and orientation of a person to psychological, social and ethical goals, an excess of information ("information explosion") that affects culture and the individual, "domocentrism" ("electronic cottage") as the main lifestyle, "personalization" is the orientation of culture and society to each about a man when he loses the features of the "mass of the individual".

What becomes innovative here is not so much the rejection of ready-made, established moral and ideological truths of the past, from traditional radio programs and television films, from collected and systematized lengthy material, from ideas that are related to each other, but the type of presentation of material consisting of disparate fragments. The modern format of mass media offers information in the form of short modular flashes - news, fragments of films and programs dissected by advertising, and having a "strange, fleeting and incoherent form". The man of this new information culture refuses to accept new modular data in standard structures and categories and strives to create his own material from mosaic information.

E. Toffler called the new type of culture that is forming in the new society a "clip culture" created from the fragments of impressions and images, the embodiment of which is "zapping"". This image does not require the inclusion of imagination, reflection, understanding, here all the time there is a "reset", "update" of information, when everything that was originally seen with virtually no time gap loses its significance, becomes obsolete. The author considers the clip culture as a component of the information culture belonging to it means an ever-widening gap between the users of the second (corresponding to the industrial society) media and the third (information) waves.

Studying the phenomenon of clip culture T.V. Semenovskikh draws attention to the fact that initially it was the media, and not the World Wide Web, that developed a universal format for presenting information - the socalled sequence of relevant clips ${ }^{11}$. A clip, in this case, is a short set of abstracts submitted without a context definition, since due to its relevance, the context for the clip is objective reality. Thus, a person is able to freely perceive and interpret the clip due to the fact that it is immersed in this same reality. As a result, the scientist deduces the definition of the so-called

\footnotetext{
${ }^{10}$ Ibid.

11 Семеновских Т.В. “Клиповое мышление” - феномен современности. URL: http://jarki.ru/wpress/2013/02/18/3208/
} 
"Clip thinking" is the process of reflecting the many diverse properties of objects, without taking into account the connections between them, characterized by fragmentation of the information flow, consistency, complete heterogeneity of incoming information, high switching speed between parts, pieces of information, lack of a holistic picture of the perception of the world.

A peculiar scientific concept was proposed by the Spanish sociologist Manuel Castells. To designate those globalization processes that occur in modern society, M. Castells introduces the concept of "information society" 12 . E.I. Knyazeva in this case draws attention to the fact that the term "informational" refers to the attribute of a specific form of social organization in which, thanks to new technological conditions arising in a given historical period, the generation, processing and transmission of information have become fundamental sources of productivity and power ${ }^{13}$.

One of the key features of the information society is the network logic of its basic structure, which explains the concept of "network society". The scientist presents social structures as network structures, seeing in this a new social morphology. The growing efficiency, mobility and flexibility that have affected all spheres of human life make it natural to switch to network forms of social organization: a network enterprise in the economy, an interactive political system, a single Internet information network.

The Thinker emphasizes that he refers to the social structure of the information age as a network society because it is created by networks of production, power and experience, which form a culture of virtuality in global flows that cross time and space. Networks are a very old form of social organization, but in the information age they become information networks reinforced by information technology. Networks have an advantage over traditional hierarchically organized morphological relationships. In addition, they are the most mobile and adaptive forms of organization, capable of developing together with their environment and the evolution of the nodes that make up the network.

The dynamism of the social structure of a network society, its global reach, caused by financial markets, military technologies, information flows, make a network society an expanding system, penetrating in various ways and with different intensities into all societies. But it is precisely these differences that are extremely important when we try to understand the real processes of life and death of a given country at a given time. A networked society is not a

\footnotetext{
${ }^{12}$ Кастельс М. Информационная эпоха: Экономика, общество и культура. М.: Гос. ун-т. Высш. шк. экономики, 2000. 607 c. URL: infoboom.univ.kiev.ua > files > Kastels

${ }^{13}$ Князева Е.И. Концепция сетевого общества М. Кастельса. URL: http://pravmisl.ru/ index.php?option=com_content\&task=view\&id=2622\&Itemid=1
} 
model for the success of modernity; rather, it is an extremely general characteristic of the emerging social structure. At one time, this was an industrial society.

A.V. Kostina exploring the conceptual approaches to the study of the information society divides them into two large groups: techno-centrist and culture-centrist approaches to information and communication ${ }^{14}$.

- in the framework of the technological approach (Z. Brzezinski, M. Mcluhan), the dominant idea is that the technotronic revolution leaves its mark on the character of imaginative perception of reality, striving for globality, on the specifics of social life, striving for fragmentation, on the features of the formation of communities that refuse to national ideologies and based either on global or on narrowly local meanings and values. In this sense, history can be represented as a specific process of information development, where the content of the economic, social and cultural components is directly related to the nature of the content of communication and the quality of knowledge circulating in this society. This idea, in essence, forms the basis of post-industrial and informational concepts that consider the historical process as part of a civilizational approach;

- the cultural-centrist approach (D.S. Robertson, A.I. Rakitov) is based on the belief that in the process of the emergence of a knowledge-based society, the role of culture "has grown tremendously". The increase in memory and, therefore, knowledge associated with the invention of writing, representatives of this direction show that this new information system produced a new management technology leading to the creation of the state. Thus, the nature of communication, the features of the dominant sign systems and the type of formalization of knowledge appear in these concepts as the main determinants of economic development, social organization and culture. At the same time, the scientist focuses on another aspect of this problem and notes that the dependence of the specifics of the sociocultural system on communication technologies is not one-sided ${ }^{15}$.

Still, the primary one is not the nature of the communication process, not the way of transmitting information that determines the features of its formalization and functioning, but the orientation and tasks of this system itself, which determines the way of communication, as well as the quality and volume of socially significant information. Those. we are talking about the

14 Костина А.В. Тенденции развития культуры информационного общества: анализ современных информационных и постиндустриальных концепций. Знание. Понимание. Умение. 2009. № 4. URL: http://zpu-journal.ru/e-zpu/2009/4/Kostina_Information_Society

${ }^{15}$ Ibid. 
fact that not information affects this system, but rather, it itself brings to life those communication technologies that correspond to its needs.

\section{Criticism as one of the components of the problem field in the research of the information society}

At the same time, it should be noted that in modern philosophy the concept of the information society causes both a series of discussions and criticism of its modern foundations, which is largely explained by the huge number of concepts that describe the transformation of society under the influence of the information revolution. In this vein, the ideas of I.D. Tuzovsky, who claims that the "post-industrial information society" has become both a ghost wandering around the world and a conceptual werewolf. Its ghostly nature is maintained by the constant expectation of its onset ${ }^{16}$.

By analyzing the theoretical and methodological contradictions of the concept of the information society, the scientist comes to the conclusion that modern society is quasi-"informational", like a utopian information society, but, as has already been seen more than once in human history, it has not really taken place in this capacity and gives the following ideas of this hypothesis:

- The planetary community (humanity) is still chewing under the conditions of "multiera" - the coexistence of fundamentally different structures and forms of organization of society on the planet. As the progress of various societies progresses, the number of multi-era terms only increases, although, of course, the tendency to a certain leveling of the difference between them exists and is specially supported. On the one hand, global civilization is trying to rebuild local cultures that differ from it in their way of life, the system of values and motivations of culture, and on the other, include them in their orbits, but at a certain distance, as original "followers".

- From the point of view of the technical paradigm that defines our daily lives, scientific, educational, cultural practices, modernity can be described as the "Digital Ages". Industrial technology has influenced the world by participating in the formation of communities that are different in terms of economic and political criteria (capitalist and statist, democratic and totalitarian). Digital technologies are also affecting our world, however, it seems that economic and political criteria are not quite suitable for explaining this influence. A criterion is needed for the practice of creating, disseminating and using social information.

\footnotetext{
${ }^{16}$ Тузовский И.Д. Утопия ХХІ века: глобальный проект “Информационное общество”. Челябинск: Челяб. гос. акад. культ. и искусств, 2014. С. 323.
} 
- The most developed communities of the planet exist in a quasi"information society" (QIS). The two most important points associated with this definition are:

- the prefix "quasi" refers specifically to the general term "information society". This is not a quasi-information society and not an information quasicommunity. This is a quasi-"information society";

- "Quasi" is not "pseudo": quasi - "something like"; pseudo - "false." QIS is a really existing society, which in its main sign resembles the information society, but neither in the present nor in the future is congruent to it. The Pseudo-Information Society (PsIS) is the "false information society". One can speak about a pseudo-information society in the case of attempts to fit into this concept those communities which, possessing a system-forming means of communication of the information society - the Internet - and the virtual community, do not meet other essentially important criteria.

- Modern society is the historical heir to the capitalist stage of the socioeconomic formation. The world economic system remains capitalistic, although this is neither wild capitalism of the era of the emergence of Marxism, nor socially responsible capitalism of large corporations during the struggle between Ford and Roosevelt. Capitalism is alive, it is the reality of a quasi-"information society".

- Historically, there already existed societies that can be recognized by us as quasi-informational. In particular, the Hellenic society of the classical period can be considered as a variant of the information society. The opinion that QIS is not a unique phenomenon for late Art Nouveau is indirectly confirmed by the fact that its temporal status is not fundamentally determined. Two opposing trends are observed:

1) the tendency to constantly shift the timing of the onset of a truly information society in the future;

2) the tendency to search for his forerunner (or social processes that initiated its formation) in the increasingly distant past of mankind ${ }^{17}$.

In this case, one can characterize modern QIS as a global technogenic society, the communication system of which is based on television and radio and digital technologies, and the economy is based on the capitalist principles of production and the consumerist ideology of mass consumption. Political power in such a society becomes a derivative of disinformation social technologies, and culture becomes just another product in a series of digital

\footnotetext{
17 Тузовский И.Д. Парадоксы информационного общества. URL: http://emag.iis.ru/arc/ infosoc/emag.nsf/BPA/b35f5dc4d0df171744257f79004d2127
} 
content. An ideal or humanistic information society must overcome a range of QIS controversies and challenges ${ }^{18}$.

V.G. Ivanov and M.L. Lezgin is generally referred to as the "information society" as a social myth that arose on the eve of the entry of humanity into the third millennium $\mathrm{AD}^{19}$. Researchers say some see the idea of an information society as the latest version of millinarism, others as a bugbear, others as a social project for the future, fourth as a successful replacement for an absent social ideal (after "rebirth", "democracy", "Orthodoxy", and others have proved its inefficiency in this capacity), fifth - an abstract image of the social system of either the United States or Japan. For some, the "information society" is an inevitable future, for others it's a poorly justified utopia, for others it's the next round of a language game.

Researchers pose the question: "What is an "information society"?", and they answer, is it an impending reality, a daring utopia, a simulacrum, a decoy for the average person, a cunning image that hides reality? There is no definite answer, because all meanings are mixed in this image. The "Information Society" is inspired by the successes of the current stage of scientific and technological progress, but it is of the same hyperbolized and mirage nature as the problems of astronautics in fiction at the dawn of going into outer space. But the image of this society is also a warning to humanity about the dangers that lurk for it in its own history and in addition to the chimeras of "global warming", "ozone holes", and "clashes of civilizations"20.

In this spirit, one can note the ideas of one of the ideologists of the concept of virtualization of the society, D. Ivanov, who notes that if you understand the theoretical meaning of the popular notion of "information society" and analyze what really happens in a turn of the century society, you can come to a paradoxical conclusion : the introduction of the so-called "information technologies" rather removes us from that information society ${ }^{21}$. The predictions of the information society theorists turned out to be untenable primarily because their authors identify information and knowledge. There is a lot of information in modern society, it plays an enormous role, but it does not at all follow that in modern society, knowledge is power. The information society, therefore, turns out to be a phantom of the post-industrial era. The

${ }^{18}$ Тузовский И.Д. Утопия XXI века: глобальный проект “Информационное общество”. Челябинск: Челяб. гос. акад. культ. и искусств, 2014. С. 324

19 Иванов В.Г., Лезгина М.Л. "Информационное общество" как продукт научнотехнического прогресса. Теоретический журнал “Сredo”. 2005. URL: http://credonew.ru/ content/view/471/57

${ }^{20}$ Ibid.

${ }^{21}$ Иванов Д. Виртуализация общества. СПб: "Петербургское Востоковедение”, 2000. URL: https://www.politology.vuzlib.su/book_o056.html 
technological changes associated with the formation of this kind of social organization are evident, and the expected changes in the institutional structure do not occur. The lesson of Marxism did not go in vain. Another ghost is doomed to wander around Europe, and at the same time America and Japan, leaving us the question of whether changes in social relations are a function of technological changes, or whether social changes are a series of technological, economic, political and other trends, the correlations between which are not at all necessarily suggest the existence of unambiguous causal relationships. The rejection of an uncritical perception of the model of the information society with its technological determinism characteristic opens the prospect of a more adequate interpretation of the computer revolution as one of the trends in the transformation of society. In this perspective, the fact that priority in recent years of the XX century. It was the development of not informational, but simulation technologies - virtual reality technologies.

Noteworthy in this case is the idea of V.M. Zhukova, who, exploring different philosophical approaches to understanding this concept, comes to the conclusion that, for all the positive aspects, the main hope of the advocates of this approach (as well as the advocates of the concept of a post-industrial society) did not materialize ${ }^{22}$. According to the scientist, the development of computer technology did not smooth out social conflicts, and in some cases even turned into a weapon of struggle (as is the case with information attacks on government resources stored on the network, the banking system, etc.). The fact that all the owners of computers now possess information resources, as it turned out, is losing its significance if people do not want or cannot fully use the capabilities of new technologies. The founders of the concept of the information society based their forecasts on the assumption that the future belongs to the technical elite. But the triumphal procession of computer technology has led to the fact that the use of a personal computer has become quite simple skills that do not imply a truly independent modeling of information reality. Moreover, the opinions and actions of an ordinary "advanced user" can be controlled from the outside even more than before (due to the increased speed of information transfer and new tools for modeling virtual reality).

Such an "information society," as some thinkers say, is a rationalized model of the technological utopia that was actively propagated in Western

\footnotetext{
22 Жукова М. В. Критика концепции информационного общества. Стратегии развития сочиальных общностей, институтов и территорий: материалы Международн. науч.практ. конф. Екатеринбург, 23-24 апреля 2015 г. Екатеринбург: Изд-во Урал. ун-та, 2015. T. 1. C. 229.
} 
society in the middle of the 20th century, but has still not been fully implemented in practice ${ }^{23}$.

As O.A. notes Stepunina, world space is turning into a computerized, single information community. Plus - life becomes more convenient, but the consequences of failure of at least one computer can become irreversible. And this is a very serious minus ${ }^{24}$. The scientist continues the positive and negative features of the information society, television perfectly demonstrates. Along with the fact that with its help monuments, cultural masterpieces are created, advertising and spam are also produced. A great many pop and rock concerts, TV shows enriching a materially defined part of society, to a large extent simplifies the human person. Society is becoming less moral and cultural.

However, despite the critical indicators in understanding the information society, it should be noted that, nevertheless, for a number of indicators, humanity has come close to the generally recognized standards of the "information society". First of all, it is about the formation of a global information industry, which is going through a period of technological convergence, organizational mergers, legislative liberalization, the role of knowledge, information in economic development, structural changes in employment.

\section{CONCLUSIONS}

A variety of scientific approaches to the study of the information society creates a problem field in the philosophical discourse on the study of this issue. The virtualization of modern society, the simulation of social reality pushed this conceptual direction to the background, highlighting the concept of virtuality and the related properties and categories of modern society. However, in modern science, the positive and negative aspects of the information society have been determined, which ultimately come down to the virtual society as its resulting manifestation.

So, among the positive qualities, one can note the understanding of information as the basis of various areas of activity, all representatives of the population have equal access to the sources of interest to them, the information does not carry harmful trends for people. It is provided for the management of the information society by state authorities. The following

${ }^{23}$ Коваль Т.И. От информационного общества к обществу знаний: реальность или отдаленное будущее? Исторические, философские, политические и юридические науки, культурология и искусствоведение. Вопросы теории и практики. 2011. № 6 (12): в 3-х ч. Ч. I. URL: http://elar.urfu.ru/handle/10995/38809

24 Степунина О.А. Характерные черты и опасные тенденции информационного общества. Молодой ученый. 2017. № 21 (1). С. 54-56. URL https://moluch.ru/archive/ 155/44089/ 
are considered negative: an increase in the impact on information of a person's life, a virtualization of the life of individuals, the problem of adapting to the field of the information society and technology (because of which they constantly need to increase their level of professionalism), a collision with virtual reality, which has absolutely opposite consequences, reduction in the number of available workers due to the expansion of informatization.

Despite the above criticisms of the concept of the information society, it should be noted that in our opinion, the information society exists as an already developed system, although it differs noticeably from the picture that was portrayed in the forecasts of the 60s-80s. twentieth century. E.N. Chernova in this case claims that no matter how consistent the criticism of the information society, the concepts of its formation have a solid empirical basis $^{25}$. There is a real strengthening of the role of fundamental sciences that have reached a high degree of theorization, and they become the source of the most progressive innovations - nanotechnology, biotechnology, information and communication technologies.

In its theoretical plan, the concept of the information society remains a systematic methodology for understanding the role of information technology in social life. In terms of worldview, there is a rethinking of the values of technological civilization, the search for alternative ways of social development, the desire for sustainable development, overcoming crisis and regressive trends, creating a model of new social relations.

Important here is the fact that the inevitable consequence of the development of society's informatization is the explosive increase in the scale and pace of virtualization, the emergence and spread of ever new forms of artificial virtual reality, the displacement of natural and spiritual being.

Society enters the technological era of its development when social processes become completely predictable and programmable. The infrastructure of the information society is a new "intellectual", rather than a "mechanical" technique. Knowledge, not ownership, is becoming a determining factor in social differentiation and social mobility. More essential for social stratification is a professional rather than class structure. The division into "haves" and "have-nots" takes on a fundamentally new character: the most informed members of society now form the privileged layer. As a result, there is a change in value attitudes.

25 Чернова Е.Н. Концепция информационного общества в современном социальном познании. Гуманитарные и социальные науки. 2010. № 6. С. 120. 


\section{SUMMARY}

Thus, the presence of a large number of studies of the information society makes it possible to draw the following conclusions. First of all, the information society at its core has very real reasons. The latter are expressed in the rapid informatization of society since the middle of the twentieth century, and in our time virtualization. This allows modern scientists to speak not so much about information as about virtual society.

In other words, thanks to information technology, mankind has acquired a completely new, almost unknown world, created and maintained with the help of high information technologies, generated by the informatization of society. It was at this time that the concept of "virtual reality" emerged as an alternative to existing social reality, which is designed to replace and compensate for a person's unrealized features or spheres of life.

Of course, as we saw, there are several points of view that are mainly divided into positive and negative understanding of the concept of the information society. In our opinion, each of them has its own grounds for judgment. The problem is that it cannot be interpreted unambiguously.

Those in fact, the concept of the information society has become a transitional methodological way of understanding the sociocultural processes that have embraced modern society. This concept offers a study of society as a model of new social relations built on the total dominance of information / computer technology. This is a model of a new type of society, which is being formed on the basis of a large-scale sociocultural transformation based on the widespread introduction of technologies in all spheres of human life. In this regard, it is enough to recall the "Komputopia" by J. Masouda, who describes it in the early 90 s of the twentieth century as a social system of the future.

Therefore, in view of the current discourse in the field of the concept of the information society, it is difficult to say whether such a specific, but already familiar society is useful for people or not. On the one hand, a person can receive development and new knowledge from such sources, but on the other hand, it can harm him very much. In any case, there is no turning back, the informatization / virtualization of society is developing rapidly, the simulation of social reality is becoming more and more indistinguishable from reality, the main thing in this direction is not to cross the line of human deportation.

\section{REFERENCES}

1. Алексеева И.Ю. Возникновение идеологии информационного общества. URL: http://www.iis.ru/events/19981130/alexeeva.ru.html

2. Белл Д. Социальные рамки информационного общества. Новая технократическая волна на Западе. М.: Прогресс, 1986. С. 330-342. 
3. Дайзард У. Наступление информационного века. Новая технократическая волна на Западе. М.: Прогресс, 1986. С. 343-356.

4. Жукова М.В. Критика концепции информационного общества. Стратегии развития социальных общностей, институтов и территорий: материаль Международн. науч.-практ. конф. Екатеринбург, 23-24 апреля 2015 г. Екатеринбург: Изд-во Урал. ун-та, 2015. Т. 1. C. $227-230$.

5. Иванов В.Г., Лезгина М.Л. "Информационное общество" как продукт научно-технического прогресса. Теоретический журнал “Credo". 2005. URL: http://credonew.ru/content/view/471/57

6. Кастельс М. Информационная эпоха: Экономика, общество и культура. М.: Гос. ун-т. Высш. шк. экономики, 2000. 606 с.

7. Князева Е.И. Концепция сетевого общества M. Кастельса. URL: http://pravmisl.ru/index.php?option=com_content\&task=view\&id=2622\&Ite $\operatorname{mid}=1$

8. Коваль Т.И. От информационного общества к обществу знаний: реальность или отдаленное будущее? Исторические, философские, политические и юридчческие науки, культурология и искусствоведение. Bопросы теории и практики. 2011. № 6 (12): в 3-х ч. Ч. I. URL: http://elar.urfu.ru/handle/10995/38809

9. Костина А.В. Тенденции развития культуры информационного общества: анализ современных информационных и постиндустриальных концепций. Знание. Понимание. Умение. 2009. № 4. URL: http://zpu-journal.ru/e-zpu/2009/4/Kostina_Information_Society

10. Крамаренко Н.С., Сомов Д.С. Виртуальный мир как новое пространство самоосуществления человека. URL: https://cyberleninka.ru> article>virtualnyy-mir-kak-novoe-prostranstvo-s...

11. Степунина О.А. Характерные черты и опасные тенденции информационного общества. Молодой ученый. 2017. № 21 (1). С. 54-56. URL https://moluch.ru/archive/155/44089/

12. Сухов Е.И. Информационное общество как новое общество. Теория $и$ практика общественного развития. 2011. URL: https://cyberleninka.ru/ article/n/informatsionnoe-obschestvo-kak-novoe-obschestvo

13. Окорокова В.В. Образ нової соціальної реальності Постмодерну та форми його моделювання: Монографія. Одеса: ВМВ, 2018. 288 с.

14. Семеновских Т.В. “Клиповое мышление" - феномен современности. URL: http://jarki.ru/wpress/2013/02/18/3208/

15. Тоффлер Э. Третья волна. М.: АCT, 2010. 784 с. URL: www.read.virmk.ru>present_past_pdf $>$ Toffler_Tretiya_volna

16. Тоффлер, Э. Шок будущего. М.: АСТ, 2002. 557 с. 
17. Тузовский И.Д. Парадоксы информационного общества. URL: http://emag.iis.ru/arc/infosoc/emag.nsf/BPA/b35f5dc4d0df171744257f79004d 2127

18. Тузовский И.Д. Утопия XXI века: глобальный проект “Информационное общество". Челябинск: Челяб. гос. акад. культ. и искусств, 2014. 389 с.

19. Чернова Е.Н. Концепция информационного общества в современном социальном познании. Гуманитарные и социальные науки. 2010. № 6. C. 112-121.

20. Masuda Y. The Informational Society as Post-Industrial Society. World Future Society. Washington: World Future Society, 1981. 171 p.

\section{Information about the author: \\ Okorokova V. V.,}

$\mathrm{PhD}$, Associate Professor,

Chair of World History and Methodology of Science, South Ukrainian National Pedagogical University after K. D. Ushynsky 26, Staroportofrankivska str., Odesa, 65020, Ukraine 